\title{
Guided inquiry lab: Its effect to improve student's critical thinking on mechanics
}

\author{
Ade Febri $^{1}$, Sajidan ${ }^{2 *}$, Sarwanto ${ }^{3}$, Dewanto Harjunowibowo ${ }^{4}$ \\ 1, 2, ${ }^{3}$ Master of Science Education, Faculty of Teacher Training and Education, Sebelas Maret University, Surakarta, Indonesia \\ ${ }^{4}$ Faculty of Engineering, The University of Nottingham, Nottingham, United Kingdom \\ *Corresponding email: sajidan@fkip.uns.ac.id
}

\begin{tabular}{|c|c|}
\hline Article Info & ABSTRACT \\
\hline Article history: & \multirow{5}{*}{ 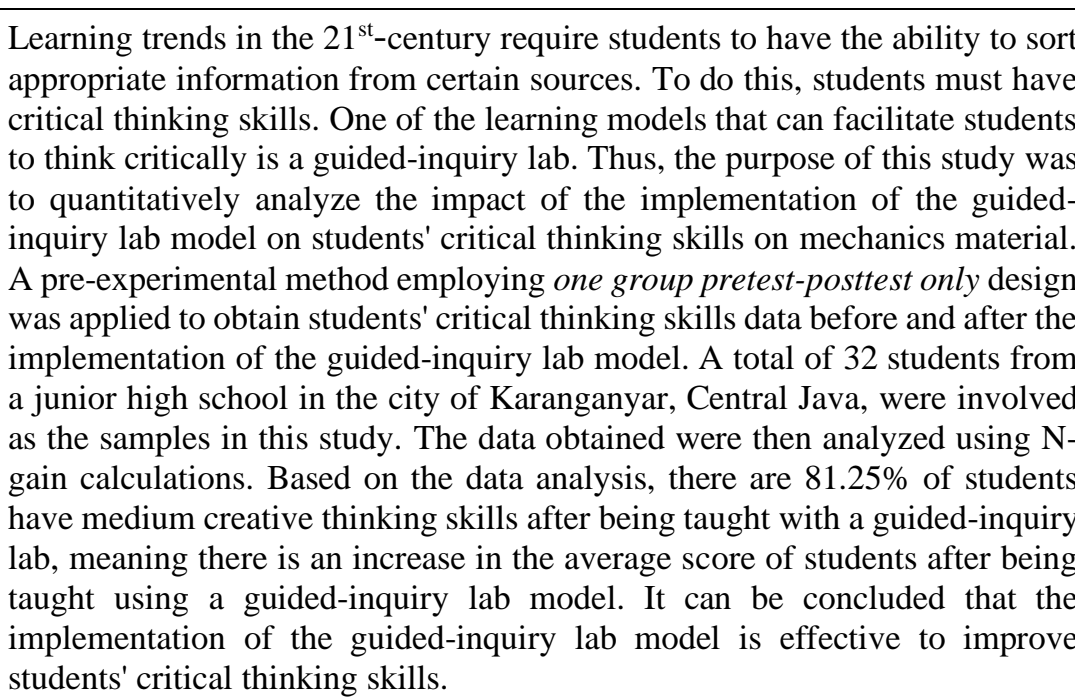 } \\
\hline $\begin{array}{l}\text { Received: August } 11^{\text {th }}, 2019 \\
\text { Accepted: February } 18^{\text {th }}, 2020\end{array}$ & \\
\hline & \\
\hline Keywords: & \\
\hline $\begin{array}{l}\text { Critical thinking; } \\
\text { Experiment method; } \\
\text { Guided-Inquiry lab }\end{array}$ & \\
\hline
\end{tabular}

(C) 2020 Physics Education Department, UIN Raden Intan Lampung, Indonesia.

\section{INTRODUCTION}

Technology is a product that follows the same pattern as items that have a life cycle of birth, growth, maturity, and decline (Holland \& Piper, 2016). Nowadays, learning technology continues to experience growth. This allows the learning process to become more effective and efficient so that better results are obtained. In science fields, they often require laboratory practice to develop an effective acquisition and hands-on experience skills (Kurniawan et al., 2019; Simbolon \& Sahyar, 2015). Therefore, education in Indonesia needs to adopt new learning methods that can support this change.

Education in the $21^{\text {st }}$ century is marked by the easy acquisition of information that encourages students to look for more information outside their classrooms (Yanti, 2016). This requires students to have the ability to sort appropriate information from certain sources. The ability to sort information and to consider it deeply before using it is known as critical thinking (Fisher, 2014).

Critical thinking and problem-solving skills are the main components of human development (Boyaci \& Atalay, 2016). The $21^{\text {st }}$ Century learning focuses on the skills known as (4C) that must be mastered by students, wherein those skills entail communication, critical thinking, collaboration, and creativity (Rusdin, 2018). The $21^{\text {st }}$ Century skills represent the characteristics that students should have in 
overcoming difficulties and achieving success (Ball et al., 2016; Shidiq \& Yamtinah, 2019).

The importance of developing critical thinking skills among students makes educational researchers propose various ways. Research conducted by Widowati et al. (2017) shows that students' critical thinking skills can be improved through learning by using the mind map. This is because the mind map is a specific type of learning activity through the organization of the mind. To some extent, it is similar to the study conducted by Sahoo \& Mohammed (2018) which shows that summary writing activities can improve students' critical thinking skills. However, mind map or writing activity is considered not optimal in improving students' thinking skills because it does not directly involve students in practicum.

This case also happened in Karanganyar Junior High School. Based on the results of the preliminary studies in one of the junior high schools in the city of Karanganyar, Central Java, students have difficulty in understanding the material of mechanics that demands experimentation and critical thinking. Therefore, innovations are needed to improve students' critical thinking and experimentation skills. One of the solutions is to use the Guided-Inquiry Lab (GIL) model.

Guided Inquiry Lab (GIL) models have been widely used on other physics topics and in many other fields of study. Such as the use of GIL in viscosity experiments (Kurniawan et al., 2019), GIL in learning biology (Castro \& Morales, 2017), and GIL in learning chemistry (Cheung, 2011). Laboratory practice has unquestionable importance in chemistry education (Ural, 2016). Students have considerable autonomy in the design and execution of the experiment (Fakayode, 2014).

According to Wenning (2011), GIL is an independent activity that can gradually train students to become more independent individuals in planning experiments and collecting data. Inquiry activities facilitate students in asking questions, honing their curiosity, and being in charge of investigation activities as well as those of formulating questions (Wenning, 2005). Prelab activities are carried out to activate students' initial knowledge while leading questioning in the form of questions is to guide students in the execution of the practice. One of the strengths of the guidedinquiry lab model depicts that it encourages students to form and develop their selfconcepts so that their understanding of concepts and ideas is stronger and their ability to apply knowledge to everyday life is increasing (Yanti, 2016).

Through this study, researchers quantitatively analyze the impact of the implementation of the guided-inquiry lab model on students' critical thinking skills on mechanics material. Several studies have stated the importance of the Guided Inquiry Lab to be applied in laboratory activities or materials that require practice. On the other hand, Guided Inquiry has been proven to be good at overcoming students' critical thinking problems. However, there has been no research on Guided Inquiry Lab to improve students' critical thinking skills on material that requires practice. This research is aimed to fill the gap. It is expected that this study can provide novelty for researchers and education practitioners to improve students' critical thinking skills using the guidedinquiry lab model.

\section{METHODS}

An experimental method employing one group pretest-posttest only design was applied to obtain students' critical thinking skills data by applying the guided-inquiry lab model (Fraenkel, 2012) as shown in Figure 1, 


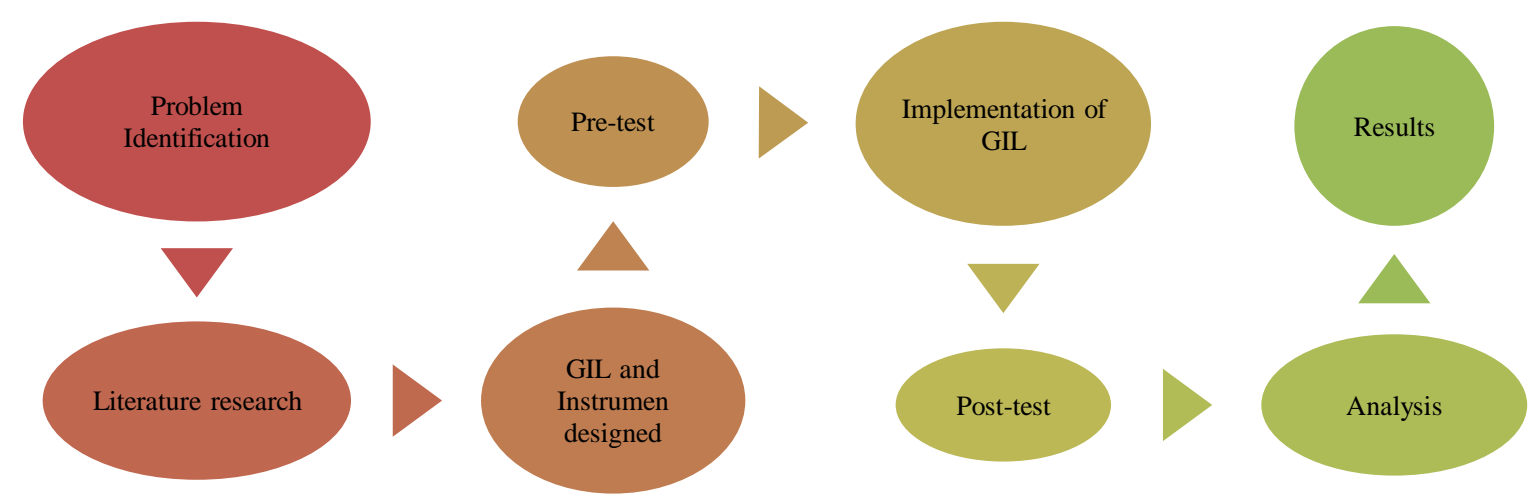

Figure 1. Research Diagram

A total of 32 students from a junior high school in the city of Karanganyar, Central Java, were involved as the samples in this study. The data obtained were then analyzed using N-gain calculations. The mechanic's materials taught are distance and displacement, uniform linear motion, accelerated linear motion, force concept, and Newton's law. A description of each meeting is shown in Table 1. The examples of learning activities in the $3^{\text {rd }}$ meeting are presented in Table 2. The instrument used was a set of questions developed by incorporating the aspects of critical thinking skills, namely interpretation, analysis, evaluation, conclusions, explanations, and self-regulation. The example of one of the questions used is presented in Table 3.

Table 1. The material taught at each meeting

\begin{tabular}{cc}
\hline Meeting & Materials \\
\hline 1st meeting & Distance and Displacement \\
2nd meeting & Uniform Linear Motion \\
3rd meeting & Accelerated Linear Motion \\
4th meeting & Force Concept \\
5th meeting & Newton's First Law \\
6th meeting & Newton's 2nd Law \\
7th meeting & Newton's 3rd Law \\
\hline
\end{tabular}

Table 2. The example of learning activity

\begin{tabular}{|c|c|c|}
\hline Learning Steps & Teacher's Activity & Students' Activity \\
\hline Observation & $\begin{array}{l}\text { Giving a phenomenon about a toy car that } \\
\text { runs on a track. The toy car is pushed so } \\
\text { that it moves along the track but it will } \\
\text { eventually stop }\end{array}$ & $\begin{array}{l}\text { Observing the demonstrations by the } \\
\text { teacher }\end{array}$ \\
\hline Manipulation & $\begin{array}{l}\text { Facilitating students to experiment with } \\
\text { toy cars, }\end{array}$ & $\begin{array}{l}\text { Identifying problems, formulating } \\
\text { problems, identifying variables, and } \\
\text { making hypotheses from the experiment }\end{array}$ \\
\hline Generalization & $\begin{array}{l}\text { Facilitating students in making a principle } \\
\text { or term that is obtained from the } \\
\text { investigation }\end{array}$ & $\begin{array}{l}\text { Summarizing the results of experiments } \\
\text { and make terms for phenomena that are } \\
\text { experimented on }\end{array}$ \\
\hline Verification & $\begin{array}{l}\text { Facilitating students in communicating, } \\
\text { comparing with other friends. } \\
\text { Facilitate students in correcting the } \\
\text { results of discussions with other groups. }\end{array}$ & $\begin{array}{l}\text { Communicating the results of } \\
\text { observations and analysis with classmates } \\
\text { through presentations. }\end{array}$ \\
\hline Application & $\begin{array}{l}\text { Facilitating students in mentioning the } \\
\text { application of the results of investigations } \\
\text { in everyday life }\end{array}$ & $\begin{array}{l}\text { Analyzing the application of the results of } \\
\text { investigations in everyday life. Students } \\
\text { look for other examples that applying the } \\
\text { same concept to the experiments } \\
\text { conducted }\end{array}$ \\
\hline
\end{tabular}


Table 3. The example of instrument for assessing critical thinking skills

\begin{tabular}{ll}
$\begin{array}{l}\text { Critical Thinking } \\
\text { Indicator }\end{array}$ & Item \\
\hline Interpretation & $\begin{array}{l}\text { A cat that is stationary on the grass then moves at a speed of } 5 \mathrm{~m} / \mathrm{s} \text {. after } 1 \text { minute } \\
\text { of walking the cat's speed becomes } 6 \mathrm{~m} / \mathrm{s} .5 \text { minutes later the cat runs at } 7 \mathrm{~m} / \mathrm{s} . \\
\text { Analyze the movements of the cat }\end{array}$ \\
\hline
\end{tabular}

\section{RESULTS AND DISCUSSION}

The purpose of this study was to quantitatively analyze the impact of the implementation of the guided-inquiry lab model on students' critical thinking skills in learning the material as regards mechanics. The study began with the provision of a pretest in the form of questions developed by referring to the aspects of creative thinking skills. The example of the question can be seen in Table 1. The implementation of guided-inquiry lab learning followed the steps as stated by (Wenning, 2011).

The application of this model began by observing a phenomenon. This thing Contains a phenomenon that guides students to formulate the problem regarding the problem (Dwiyanti et al., 2016). The problem or situation had to be based on an idea that could indeed be found (a discoverable idea). After the situation was presented to students, they first needed to investigate several aspects of this situation, for example, the nature and identity of objects and events related to the situation (Ahmadi, 2010). The hallmark of the problem presented by the teacher was the conflict involved between students' understanding and reality. The situation that contrasted with an expectation caused students to wonder what was happening, and it resulted in cognitive imbalance.

Through appropriate instructions, students could try to find differences and find the explanation that was the most appropriate to the event. Observation of a phenomenon can also begin with the teacher preparing questions for students because the questions are the basis for scientific inquiry (Santoso et al., 2018). Asking the right questions is very important in an investigation. One of the questioning techniques that teachers use most often is writing questions on the board, but such a technique does not guide students to achieve learning goals. Natural science teachers should be able to encourage students to state what they think, test and explain their findings using the pedagogy that reflects scientific inquiry and strategies recommended by cognitive psychology.

The second step in the guided-inquiry lab model was manipulation. In this activity, students were asked to identify all variables that affected the phenomenon presented by the teacher and then conduct experiments following the design in the first step. Hence, students would collect data following the variables that were considered influential earlier. Data collection was a mental process that was very important in intellectual development.

The third step was generalization where students made observations and then communicated the results to other groups. Students were also asked to analyze relationships and made principles out of what was done. Analyzing the relationships between variables meant the ability to think rationally. In this sense, the truth of the answers given was not only based on argumentation but must be supported by the data found and could be justified.

The fourth step was verification by comparing the results that were found with others'. At this stage, students conducted a careful examination to prove whether the principles stated earlier were correct or not compared to the alternative findings and linked to the results of data processing.

The fifth step was generalization by linking the acquired knowledge to everyday life. At this stage, students were encouraged to use and apply the concepts they had learned from the previous stage in different situations. 
Each step of the guided-inquiry lab model is associated with the aspects of critical thinking skills as proposed by Facione (2015). The first step in the guided-inquiry lab model accommodates two types of aspects in critical thinking skills, namely interpreting and analyzing. The ability to interpret is of importance to be possessed by students because it trains students to describe something and look for relationships and certain patterns of the observed phenomena. Likewise with the next steps, in detail, the association is presented in Table 4.

Table 4. The steps of guided-inquiry lab model according to wenning (2011) associated with the aspects of critical thinking skills according to faicone (2015)

\begin{tabular}{|c|c|c|}
\hline $\begin{array}{l}\text { Learning } \\
\text { Steps }\end{array}$ & Learning Process & $\begin{array}{l}\text { Aspects of } \\
\text { Critical Thinking } \\
\text { Skills }\end{array}$ \\
\hline \multirow[t]{2}{*}{ Observation } & $\begin{array}{l}\text { Creating a trial design through pre-lab activities (group } \\
\text { discussion) and multiple leading questioning (leading } \\
\text { questions) }\end{array}$ & Interpretation \\
\hline & Students observe phenomena and are asked questions & Analysis \\
\hline \multirow[t]{4}{*}{ Manipulation } & $\begin{array}{l}\text { Students are encouraged to identify all of the variables } \\
\text { concerned }\end{array}$ & Analysis \\
\hline & $\begin{array}{l}\text { Students are asked to distinguish between unrelated } \\
\text { variables }\end{array}$ & Analysis \\
\hline & $\begin{array}{l}\text { Students are encouraged to identify the independent } \\
\text { variables that affect the dependent variable }\end{array}$ & Analysis \\
\hline & $\begin{array}{l}\text { Students are asked to experiment under the previous } \\
\text { experimental design }\end{array}$ & Analysis \\
\hline \multirow[t]{4}{*}{ Generalization } & Making observations & Analysis \\
\hline & $\begin{array}{l}\text { Recording the results of the experiment and } \\
\text { communicating the results to other groups }\end{array}$ & Analysis \\
\hline & $\begin{array}{l}\text { Students are asked to analyze the relationship between } \\
\text { influential variables }\end{array}$ & Analysis \\
\hline & $\begin{array}{l}\text { Students are asked to make a principle or term that is } \\
\text { obtained from the investigation }\end{array}$ & Conclusion \\
\hline \multirow[t]{2}{*}{ Verification } & $\begin{array}{l}\text { Communicating and comparing with other friends' } \\
\text { findings }\end{array}$ & Explanation \\
\hline & Correcting the results of other group discussions. & Self-regulation \\
\hline \multirow[t]{2}{*}{ Application } & $\begin{array}{l}\text { Students mention the application of the results of } \\
\text { inquiry in everyday life }\end{array}$ & Evaluation \\
\hline & Working on evaluation questions & Evaluation \\
\hline
\end{tabular}

At the end of the lesson, a posttest was given to students to see the increase in their critical thinking skills. Students' pretest and posttest data processing were calculated using the $\mathrm{N}$-gain formula. The results are shown in Figure 2. Based on this $\mathrm{N}$-gain calculation, students' critical thinking skills could be grouped. The criteria for grouping students based on $\mathrm{N}$-gain values are presented in Table 5.

$$
\begin{aligned}
& \text { N-Gain }=\frac{\text { Tpost }-T_{\text {pre }}}{T_{\text {maks }}-T_{\text {pre }}} \\
& \text { Note: } \\
& \text { Tpost: The average score of Posttest } \\
& \text { Tpre: The average score of pretest } \\
& \text { Tmax: Ideal maximum score }
\end{aligned}
$$

Table 5. The category of the obtained N-gain score

\begin{tabular}{cc}
\hline Score $($ g) & Category \\
\hline$(\mathrm{g})>0,7$ & High \\
$0,3<(\mathrm{g}) \leq 0,7$ & Medium \\
$(\mathrm{g}) \leq 0,3$ & Low \\
\hline
\end{tabular}




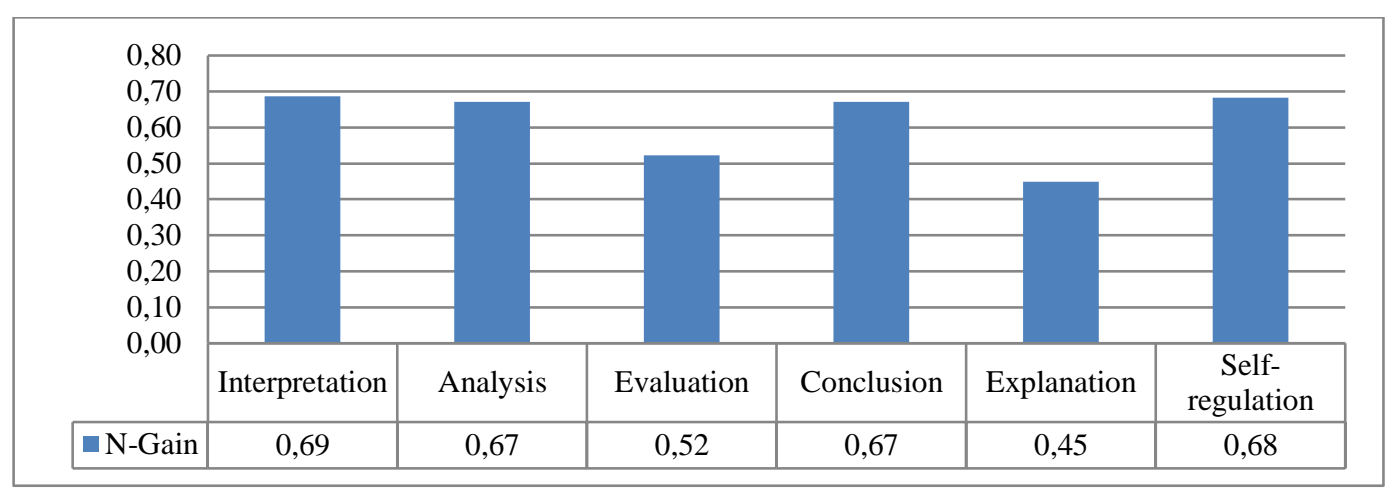

Figure 2. Graph of the increase in students' critical thinking skills

Critical thinking skills are the active processes of a person is thinking about a thing in-depth, asking questions, and finding relevant information. According to Fisher (2014), critical thinking is an activity of rational and reflective thinking by focusing on the problem or idea at hand. Critical thinking requires careful consideration, good analysis, testing, and evaluation. The obtained $\mathrm{N}$-gain value in each aspect of critical thinking skills was different. In the guided-inquiry laboratory, students are only given the problems and they must plan the investigation, collect and organize their data, and make evidence-based conclusions (Mulyana et al., 2018; Sofiani et al., 2018). However, each aspect was in the medium category.

Interpretation is the ability of a person to understand and express the meaning or intent of various experiences in situations, data, events, decisions, conventions, the trustworthiness of rules, procedures, or criteria (Susilowati et al., 2017). This phase helped students comprehend explanations consistently with evidence provided based on observations and data collection from the results of the experiment (Arianto et al., 2018). In this study, pertinent to the aspect of interpretation, the obtained $\mathrm{N}$-gain value was 0.69 so that it was categorized into the medium category. However, the obtained value almost touched the number 0.7 which was classified into a high categorized number. This meant that students were able to see the problem or phenomenon presented by the teacher from various points of view with the implementation of the guidedinquiry lab model. It is because students learn natural science by using a sort of understanding derived from their interpretation of a phenomenon (Seventika et al., 2018).

The analysis is the ability to identify the true intentions and conclusions between statements, questions, concepts, descriptions based on beliefs, decisions, experiences, reasons, information, or opinions (Susilowati et al., 2017). In this study, the $\mathrm{N}$-gain value for the aspect of the analysis was 0.67 , and it was also categorized into the medium category. The inquiry learning model is a learning model that provides opportunities for students to be active in solving problems and formulating their conclusions so that they have meaningful learning experiences. This learning can make students assume to solve problems by posing questions then getting their answers based on analysis and investigation. Thus, this learning can access many types of thought processes, including students' critical and creative thinking.

Evaluation is the ability to assess the credibility of statements or other presentations by assessing or describing a person's perceptions, experiences, situations, beliefs, or decisions, and using the logical power of actual inferential relationships between statements, questions, descriptions and other forms of representation (Susilowati et al., 2017). In this study, the aspect of evaluation obtained a lower $\mathrm{N}$-gain value compared to the two previous aspects. That was because the formation of scientific 
explanations was a combination of reason and evidence. The combination as such required an evaluation of the proposed ideas. It was like when taking into account the effects of a treatment or ensuring a causal relationship. Alternative explanations must be considered when assessing the validity of the explanations and conclusions obtained from the investigation. Students were not accustomed to conducting evaluations on the results obtained or in terms of the process carried out.

The inference is the ability of students to identify and choose the elements needed to draw reasonable conclusions or to formulate hypotheses by paying attention to relevant information and reducing the consequences arising from data, statements, principles, evidence, judgments, opinions, descriptions, expressions, beliefs, as well as other forms of representation (Susilowati et al., 2017). Concerning the aspect of inference, the obtained $\mathrm{N}$-gain value was 0.67 . This meant that students were able to make use of their thoughts in making inference after finding out the core of the questions asked, and then make conclusions from such core points.

Explanation portrays the ability of a person to state the results of consideration process; the ability to justify that a reason is based on evidence, methodology, concepts, or a certain criterion and reasonable considerations; and the ability to present reasons in the form of convincing arguments (Susilowati et al., 2017). In this study, the aspect appertaining to explanation obtained the lowest $\mathrm{N}$-gain value, which was 0.44 .
This meant that students were less critical in presenting explanations after conducting experiments. Some students had difficulty in understanding the information they had gathered and built an explanation about it. Students provided inadequate explanations or did not discuss essential matters. Sometimes several theories or explanations were the bases of the same data.

Self-regulation is related to a person's awareness to monitor his/her cognition, the elements used in thinking, and the results that are developed, especially by applying the ability to evaluate his/her ability to conclude in the form of questions, confirmations, validations, and corrections (Susilowati et al., 2017). In this study, this aspect obtained an $\mathrm{N}$-gain value of 0.68 . It meant that students were able to analyze the patterns of laboratory inquiry they were undertaking. Students might determine the most effective, productive and non-productive variables or the type of information that they needed and that they did not need. This phase is important if students want the inquiry process to be something that needs awareness and is systematic as well as can be proven.

In general, an increase in students' critical thinking skills could be classified into high, medium, and low categories based on the Ngain values obtained. This could be used as a reference to see how much the effect of the guided-inquiry lab model application was in improving critical thinking skills. The results of the categorization are shown in Figure 3,

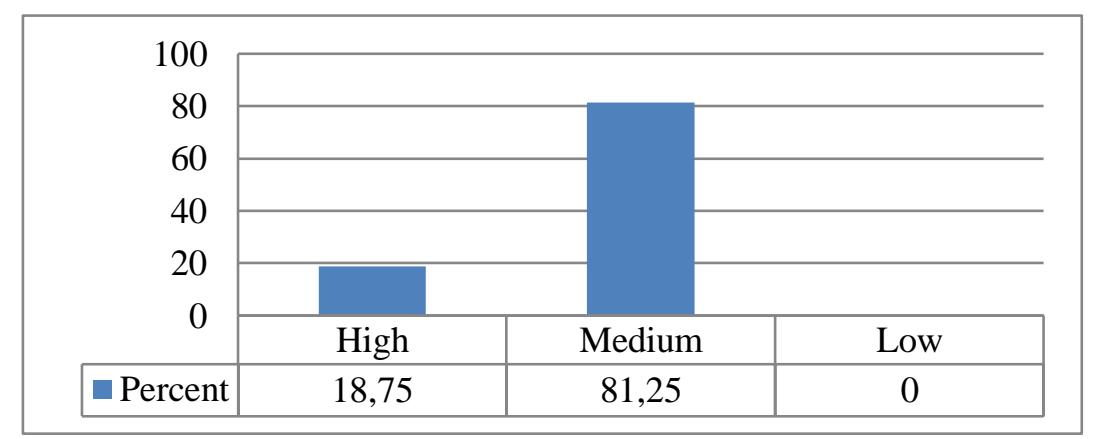

Figure 3. The category of critical thinking skills 
Based on Figure 3, 81.25\% of students had undergone an increase in critical thinking skills in the medium category. In the meantime, in the high category, there were $18.75 \%$ of students. These results proved that the application of the guided-inquiry lab model was effective in increasing students' critical thinking skills. Also, the absence of students belonging to those with the lowcategory increase in critical thinking skills further strengthens the findings of this study.

The use of guided-inquiry lab model is not only proven to improve critical thinking skills, but based on previous research it can also improve students' scientific literacy (Yanti, 2016), reduce misconceptions (Habibbulloh \& Jatmiko, 2017), enhance the interests and attitudes of students and teachers towards the lesson (Cheung, 2011), and improve laboratory skills (Allen et al., 2009).

Also, there have been many other studies conducted to improve students' critical thinking skills, such as the studies concerning with the use of guided inquiry models (Duran \& Dökme, 2016; Nisa et al., 2018; Yerimadesi et al., 2019; Zain \& Jumadi, 2018), contextual teaching and learning (Gayatri et al., 2018; Wahyuningtyas \& Wuryadi, 2018), problem-based learning (Yuliati et al., 2018), the use of concept maps (Samawi, 2006), the use of various media (Astuti et al., 2018; Hayes \& Devitt, 2008; Herpiana et al., 2019; Popescu \& Morgan, 2007; Santoso et al., 2018), and the use of various instruments (Hiedringhaus, 2001). Previous research has shown that guided inquiry lab can be used to promote student's problem-solving skills, but our findings indicate that creative thinking is the beginning of problem-solving skills. The superiority of this model is giving the chance to students more active to construct the knowledge so the student learning achievement can be maximal (Windiastuti et al., 2018).

Several studies have stated the importance of the Guided Inquiry Lab to be applied in laboratory activities or materials that require practice. On the other hand, Guided Inquiry has been proven to be good at overcoming students' critical thinking problems. However, there is no research on Guided Inquiry Lab to improve students' critical thinking skills on material that requires practice. This research is here to fill the gap. These findings can be used by teachers and education practitioners to improve students' critical thinking skills in physics and other subjects.

\section{CONCLUSION AND SUGGESTION}

The results of data analysis show that the $\mathrm{N}$-gain value on each aspect of critical thinking skills is in the medium category. This means that the guided-inquiry lab model has an impact on students' critical thinking skills. The impact is quite significant because there is an increase in the average score of students after being taught using a guidedinquiry lab model. As the implication, this study can be used as a reference in developing teaching materials that accommodate students' critical thinking skills that are conformed to the guidedinquiry lab model.

For the next step of this research, the findings of this research can be used by teachers and education practitioners to improve students' critical thinking skills in physics and other subjects.

\section{AUTHOR CONTRIBUTIONS}

AF, SJ and SW collected, analysed data. $\mathrm{AF}$ and $\mathrm{DH}$ writing result and discussion. $\mathrm{S}$ prepared research design. DH reviewing literature and conceptualization.

\section{REFERENCES}

Ahmadi. (2010). Konstruksi Pengembangan Pembelajaran. Jakarta: Prestasi Pustaka.

Allen, J. B., Barker, L. N., \& Ramsden, J. H. (2009). Guided inquiry laboratory. Journal of Chemical Education, 63(6), 533. https://doi.org/10.1021/ed063p533 Arianto, I. S., Wiyanto, \& Sujarwata. (2018). Analysis of students' ability with 
inquiry laboratory activities in archimedes'. Journal Physics Communiation, 2 (2), 94-102.

Astuti, I. A. D., Dasmo, D., Nurullaeli, N., \& Rangka, I. B. (2018). The impact of pocket mobile learning to improve critical thinking skills in physics learning. Journal of Physics: Conference Series, 1114 (1). https://doi.org/10.1088/17426596/1114/1/012030

Ball, A., Joyce, H. ., \& Butcher, D. . (2016). Exploring 21st century skills and learning environments for middle school youth. International Journal of School Social Work, 1 (1) 1-15.

Boyaci, S., \& Atalay, N. (2016). A Scale Development for 21st Century Skills of Primary School Students: A Validity and Reliability Study. International Journal of Instruction, 9 (1), 133-148.

Castro, J. A. F., \& Morales, M. P. E. (2017). "Yin" in a guided inquiry biology classroom - Exploring student challenges and difficulties. Journal of Turkish Science Education, 14(4), 4865.

https://doi.org/10.12973/tused.10212a

Cheung, D. (2011). Teacher beliefs about implementing guided-inquiry laboratory experiments for secondary school chemistry. Journal of Chemical Education, 88(11), 1462-1468. https://doi.org/10.1021/ed1008409

Duran, M., \& Dökme, I. (2016). The effect of the inquiry-based learning approach on student's critical-thinking skills. Eurasia Journal of Mathematics, Science and Technology Education, 12(12), 2887-2908. https://doi.org/10.12973/eurasia.2016.0 2311a

Dwiyanti, G., Suryatna, A., \& Taibah, I. (2016). Development of guided inquirybased student lab worksheet on the making pineapple flavoring. Journal of Physics: Conference Series, Ser. 81201, $1-8 . \quad$ https://doi.org/10.1088/17426596/755/1/011001
Facione, P. A. (2015). Critical Thinking: What It Is and Why It Counts. Thinking. San Francisco: Whitman Institute.

Fakayode, S. O. (2014). Guided-inquiry laboratory experiments in the analytical chemistry laboratory curriculum. Analytical and Bioanalytical Chemistry, 406(5), 1267-1271. https://doi.org/10.1007/s00216-0137515-8

Fisher, A. (2014). Berfikir Kritis: Sebuah Pengantar. Jakarta: Erlangga.

Fraenkel. (2012). How to Design and Evaluate Research in Education. New York: Mc Graw Hill.

Gayatri, T., Soegiyanto, H., \& Rintayati, P. (2018). Development of contextual teaching learning-based audio visual adobe flash media to improve critical thinking ability of geography learning at senior high school. IOP Conference Series: Earth and Environmental Science, $145(1)$. https://doi.org/10.1088/17551315/145/1/012004

Habibbulloh, M., \& Jatmiko, B. (2017). Pengembangan perangkat pembelajaran model guided discovery berbasis lab virtual untuk mereduksi miskonsepsi siswa SMK topik efek fotolistrik. Jurnal Penelitian Fisika Dan Aplikasinya, 07(01).

Hayes, K. D., \& Devitt, A. A. (2008). Classroom discussions with student-led feedback: A useful activity to enhance development of critical thinking skills: Food science education research. Journal of Food Science Education, 7(4), 65-68. https://doi.org/10.1111/j.15414329.2008.00054.x

Herpiana, R., Rosidin, U., \& Abdurrahman, A. (2019). Development of instruments to train critical and creative thinking skills in physics assessment for high school students' learning. Journal of Physics: Conference Series, 1155(1). https://doi.org/10.1088/17426596/1155/1/012046 
Hiedringhaus, L. K. (2001). Assignments to assess critical thinking skills : A holistic approach. Thinking, 15(3), 9-17.

Holland, D. D., \& Piper, R. T. (2016). Testing a technology integration education model for millennial preservice teachers. Journal of Educational Computing Research, 54(2), 196-224. https://doi.org/10.1177/0735633115615 129

Kurniawan, W., Jufrida, J., Basuki, F. R., Ariani, R., \& Fitaloka, O. (2019). Virtual laboratory based guided inquiry: Viscosity exsperiments. JIPF (Jurnal Ilmu Pendidikan Fisika), 4(2), 91-98. https://doi.org/10.26737/jipf.v4i2.1069

Mulyana, S., Rusdi, R., \& Vivanti, D. (2018). The effect of guided inquiry learning model and scientific performance on student learning outcomes. Indonesian Journal of Science and Education, 2(1), 105-109.

https://doi.org/10.31002/ijose.v2i1.596

Nisa, E. K., Koestiari, T., Habibbulloh, M., \& Jatmiko, B. (2018). Effectiveness of guided inquiry learning model to improve students' critical thinking skills at senior high school. Journal of Physics: Conference Series, 997(1). https://doi.org/10.1088/17426596/997/1/012049

Popescu, A., \& Morgan, J. (2007). Teaching information evaluation and critical thinking skills in physics classes. The Physics Teacher, 45(8), 507-510. https://doi.org/10.1119/1.2798365

Rusdin, N. M. (2018). Teachers' readiness in implementing 21 st century learning. International Journal of Academic Research in Business \& Social Sciences, 8, 1293-1306.

Sahoo, S., \& Mohammed, C. A. (2018). Fostering critical thinking and collaborative learning skills among medical students through a research protocol writing activity in the curriculum. Korean Journal of Medical Education, $\quad 30(2), \quad$ 109-118. https://doi.org/10.3946/kjme.2018.86

Samawi, Z. (2006). The effect of concept mapping on critical thinking skills and dispositions of junior and senior baccalaureate nursing students. In Proc. of the Second Int. Conference on Concept Mapping (pp. 2-5). Costa Rica. Santoso, T., Yuanita, L., \& Erman, E. (2018). The role of student's critical asking question in developing student's critical thinking skills. Journal of Physics: Conference Series, 953(1). https://doi.org/10.1088/17426596/953/1/012042

Seventika, S. Y., Sukestiyarno, Y. L., \& Mariani, S. (2018). Critical thinking analysis based on Facione (2015) Angelo (1995) logical mathematics material of vocational high school (VHS). Journal of Physics: Conference Series, 983(1). https://doi.org/10.1088/17426596/983/1/012067

Shidiq, A. S., \& Yamtinah, S. (2019). Preservice chemistry teachers' attitudes and attributes toward the twenty-first century skills. In Journal of Physics: Conference Series (Vol. 1157). https://doi.org/10.1088/17426596/1157/4/042014

Simbolon, D. H., \& Sahyar. (2015). Pengaruh model pembelajaran inkuiri terbimbing berbasis eksperimen riil dan laboratorium virtual terhadap hasil belajar fisika siswa. Jurnal Pendidikan Dan Kebudayaan, 21(3), 299-315. https://doi.org/10.24832/jpnk.v21i3.19 2

Sofiani, D., Nurhayati, Sunarya, Y., \& Suryatna, A. (2018). Development of guided inquiry-based laboratory worksheet on topic of heat of combustion. Journal of Physics: Conference Series, 983(1). https://doi.org/10.1088/17426596/983/1/012169

Susilowati, Sajidan, \& Ramli, M. (2017). Analisis keterampilan berpikir kritis siswa madrasah aliyah negeri di 
kabupaten magetan. Seminar Nasional Pendidikan Sains 2017 Dengan Tema "Strategi Pengembangan Pembelajaran Dan Penelitian Sains Untuk Mengasah Keterampilan Abad 21 (Creativity and Innovation, Critical Thinking and Problem Solving, Communication, Collaboration/4C)", 21(2000), 223231. Retrieved from http://www.jurnal.fkip.uns.ac.id/index. $\mathrm{php} / \mathrm{snps} /$ article/viewFile/11417/8102

Ural, E. (2016). The effect of guided-inquiry laboratory experiments on science education students' chemistry laboratory attitudes, anxiety and achievement. Journal of Education and Training Studies, 4(4), 217-227. https://doi.org/10.11114/jets.v4i4.1395

Wahyuningtyas, R. S., \& Wuryadi, W. (2018). The influence of contextual teaching and learning (CTL) on critical thinking ability and conceptual understanding of skeletal system materials. AIP Conference Proceedings, 2021.

https://doi.org/10.1063/1.5062828

Wenning, C. J. (2005). Levels of inquiry: Hierarchies of pedagogical practices and inquiry processes. Journal of Physics Teacher Education Online, 2(3), 3-11.

Wenning, C. J. (2011). The levels of inquiry model of science teaching. Journal of Physics Teacher Education Online, 6(2), 9-16.

Widowati, A., Widhy, P., \& SW, W. (2017). Peningkatan kemampuan berpikir kritis mahasiswa melalui problem based learning disertai mind map. Jurnal Biologi Edukasi Edisi, 9(1), 6-15.

Windiastuti, E. P., Suyono, \& Kuntjor, S. (2018). Development of the guided inquiry student worksheet for biology grade 11th senior high school. JPPS (Jurnal Penelitian Pendidikan Sains), 7(2), 1513-1518.

Yanti. (2016). Pengembangan modul berbasis guided inquiry laboratory (GIL) untuk meningkatkan literasi sains dimensi konten. Jurnal Inkuiri, 5(22527893), 105-111.

Yerimadesi, Y., Bayharti, B., Azizah, A., Lufri, L., Andromeda, A., \& Guspatni, G. (2019). Effectiveness of acid-base modules based on guided discovery learning for increasing critical thinking skills and learning outcomes of senior high school student. Journal of Physics: Conference Series, 1185(1). https://doi.org/10.1088/17426596/1185/1/012151

Yuliati, L., Fauziah, R., \& Hidayat, A. (2018). Student's critical thinking skills in authentic problem based learning. Journal of Physics: Conference Series, 1013(1). https://doi.org/10.1088/17426596/1013/1/012025

Zain, A. R., \& Jumadi. (2018). Effectiveness of guided inquiry based on blended learning in physics instruction to improve critical thinking skills of the senior high school student. Journal of Physics: Conference Series, 1097(1). https://doi.org/10.1088/17426596/1097/1/012015 